\title{
Selection of Inventory Valuation Method Using Fifo and Weighted Averaged
}

\author{
Aulia Azahra ${ }^{1}$, Rahmat Siauwijaya ${ }^{2 *}$ \\ ${ }^{1,2}$ Accounting Department, Faculty of Economics and Communication \\ Bina Nusantara University \\ Jakarta 11480, Indonesia \\ aulia.azahra@binus.ac.id; rahmat.siauwijaya@binus.ac.id \\ *Correspondence: rahmat.siauwijaya@binus.ac.id
}

\begin{abstract}
The research aims to analyze the factors that influence the selection of inventory valuation methods. This study employs case questions and SPSS version 24 to answer the research questions. Seventy-three manufacturing firms listed in the Indonesian stock exchange from 2010-2019 were selected with the purposive sampling method and analyzed with binary logistic regression. The results reveal that the selection of inventory valuation method affected taxes, net income, and ending inventory. Moreover, it is found that Inventory turnover and gross profit margin significantly affect inventory valuation selection methods. In contrast, current ratio and financial leverage do not significantly affect inventory valuation selection methods.
\end{abstract}

Keywords: Selection of inventory valuation methods; taxes; net income; ending inventory; current ratio; inventory turnover; financial leverage; gross profit margin.

\section{INTRODUCTION}

\section{Research Background}

Based on Statement of Financial Accounting Standards (PSAK) No. 14 (2008), inventories are defined as assets available for sale in ordinary business operations, in the production process, or the form of raw materials or equipment used in the production process or the rendering of services. While, Inventory costs consist of purchase, conversion, and other costs incurred until the inventories are in their current condition and location. Additionally, The recognized inventory valuation methods are the First In First Out (FIFO) and the Weighted Average method.

According to Teplicka, K. and Senova, A. (2020), inventory is a current asset that represents the firm's value, affecting its profit and financial results. Moreover, Weygandt, J. J., Kimmel, P.D., Kieso, D.W. (2015) stipulate that some inventory cannot be sold directly in manufacturing firms. Therefore, manufacturing companies classify inventories into three categories: finished goods, work in process, and raw materials. Finished goods inventories are manufactured goods that have been completed and are ready to be sold. Work in progress is the portion of inventory that has been produced but not yet completed. Then, raw materials are basic goods that have not been processed into production. Thus, according to Siyanbola, T.T. (2012), inventory is one of the most valuable current assets for any trading organization such as manufacturing companies because it is the secondlargest item after fixed assets on the balance sheet. In addition, Nosiru, AA (2015) argued that the valuation method is employed to determine the values of unsold inventory, cost of goods sold, and other transactions such as the purchase of inventory, which will be reported at the end of an accounting period. 


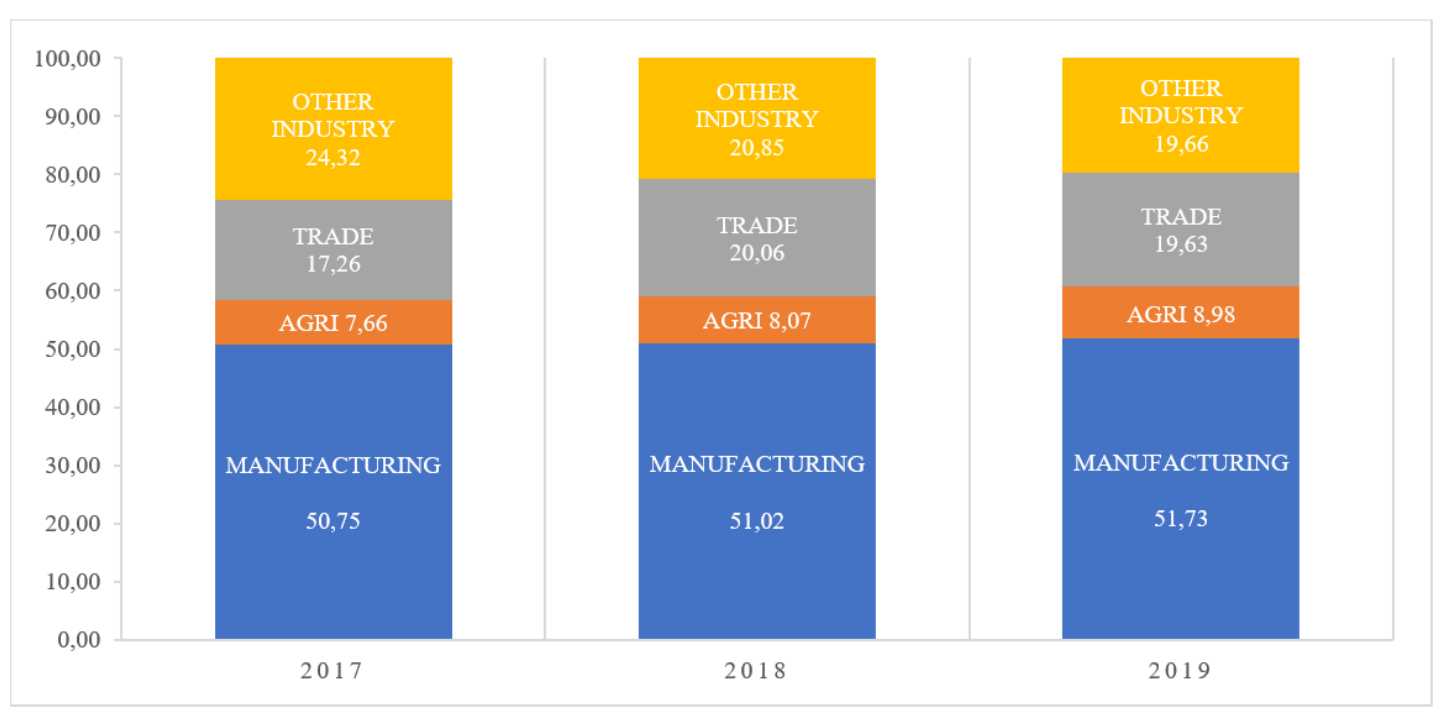

Figure 1. Percent (\%) of Inventory by Industry Sector

(Source: Processed Data)

Figure 1.1 illustrates the total percentage of the total inventory in manufacturing, agriculture, trade, and other industries. The total percentage of inventory in manufacturing companies from 2017-2019 is consistently above $50 \%$ and increased by $0.98 \%$ from $50.75 \%$ to $51.73 \%$. Moreover, manufacturing firms controlled $50.75 \%$ of the entire industry in 2017, while agriculture controlled the inventories by $7.66 \%$, trade $17.26 \%$, and other industries $24.32 \%$. Additionally, manufacturing firms managed $51.73 \%$ of the total industrial inventories in 2019; agriculture $8.98 \%$, trade $19.63 \%$, and other industries $19.66 \%$.

The selection of inventory valuation methods for companies, especially those engaged in the manufacturing sector, is essential because this sector has a high amount of inventory compared to the others. Moreover, Simeon, E.D., and John, O. (2018) argued with their case question that the selection of an inventory valuation method could affect taxes, profits, and ending inventory, proving the importance of choosing an inventory valuation method. Thus, using Simeon, E.D. and John, O. (2018) selection methods, this study aims to gauge the impact of inventory valuation methods and analyze the factors that can influence it.

The factors that can influence the selection of inventory methods for manufacturing companies have been studied by several researchers, such as Mahardika, R., Nuraina, E., Widhianningrum, P. (2015) and Rahmayani, A.N., Utami, W.P. (2019). The differences between this study and previous research are the more comprehensive analysis achieved by combining the separately studied variables. Inventory variability and cost of goods sold variables were not employed in this study due to limited data.

\section{Identification of problems}

Inventory is an asset available for sale and is a type of current asset. Manufacturing companies classify inventories into three categories: finished goods, work in process, raw materials; therefore, some inventories cannot immediately be sold into the market. The selection of different inventory valuation methods between manufacturing companies is suspected to be one of the factors that can affect taxes, profits, and ending inventory. In addition, some factors can influence the selection of inventory valuation methods, and those will be listed in the following section.

\section{Research Purposes}

Based on the previously mentioned background and problem identification, the objectives of this research are to study manufacturing firms and find out:

1. Effect of the selection of inventory valuation methods on tax, profit, and ending inventory.

2. Effect of inventory turnover on the selection of inventory valuation methods.

3. Effect of the current ratio on the selection of inventory valuation methods.

4. Effect of financial leverage on the selection of inventory valuation methods.

5. Effect of gross profit margin on the selection of inventory valuation methods. 


\section{Literature Review}

Positive accounting theory developed by Watts and Zimmerman (1990) explains and predicts firms' chosen accounting policies and practices under certain conditions. Moreover, a firm's management tends to take an opportunistic behavior in making policy decisions.

The First In First Out (FIFO) method applies the method where the earliest inventory purchased by a firm is sold first on the assumption that by decreasing the cost of goods sold, profits will be higher, which results in a higher tax for the firm. The weighted average valuation method is a calculation method that provides consistent inventory values because it combines costs and output between the previous period and the current period. Thus, the new average price will be determined by dividing the total cost of materials available by the total units in stock (Emmanuel, O., Abdullahi, Y.U., 2015).

Inventory Turnover or also known as inventory intensity measures how much inventory is sold in one year. Thus, if the company has a high level of inventory intensity or a low level of inventory, it shows efficiency in inventory management.

The current ratio shows the efficiency of the company's operating cycle or its ability to convert products into current assets. Current assets are assets that can be converted into cash. The higher the current ratio, the more liquid the company is.

Financial leverage is a ratio that describes the company's ability to manage its obligations to pay debts using the total assets or capital owned. In this study, the financial leverage variable is proxied by the debt to asset ratio.

Gross profit margin is an analysis used to determine gross profit from one period to the next period. This ratio can be calculated by dividing gross profit by net sales.

\section{METHODS}

\section{Data Types and Sources}

The type of data used in this study is secondary data, taken from Indonesian manufacturing firms' balance sheets and income statements. The employed components of secondary data are inventory, cost of goods sold, sales revenue, current assets, total assets, current liabilities, total liabilities, and gross profit. The data was obtained from the December $31^{\text {st }}$ annual report of manufacturing firms and sourced from the official website of the Indonesia Stock Exchange (https://www.idx.co.id).

\section{Population and Sampling Techniques}

The population in this study is all manufacturing firms listed in the Indonesian stock exchange for 20102019. The method used in the sample selection is purposive sampling. Purposive sampling is a sampling technique from the population. The technique is based on several criteria that qualify data from the population. Thus, to sample data from the population, the following are several criteria for data analysis of this study:

1. The manufacturing companies must have provided audited financial statements and have inventory items, current assets, total assets, current liabilities, total liabilities, sales revenue, and gross profit.

2. The financial statements used are in the Rupiah currency.

3. The manufacturing companies must use the FIFO inventory valuation method and weighted average.

\section{Operationalization of Research Variables}

The operationalization of variables used in this study can be seen in the table below:

Table 1. Operationalization of Research Variables

\begin{tabular}{cccc}
\hline Code & Variable & Indicator & Scale \\
\hline \multirow{2}{*}{ X1 } & Inventory Turnover & $\mathrm{IP}=\frac{\text { Cost of Good Sold }}{\text { Average Inventory }}$ & Ratio \\
& & & \\
\hline
\end{tabular}




\begin{tabular}{llll}
\hline X2 & Current Ratio & $\mathrm{RL}=\frac{\text { Current Asset }}{\text { Current Liability }}$ & Ratio \\
\hline $\mathrm{X} 3$ & Financial Leverage & $\mathrm{FL}=\frac{\text { Non Current Liability }}{\text { Total Current Asset }}$ & Ratio \\
\hline $\mathrm{X} 4$ & Gross Profit Margin & $\mathrm{MLK}=\frac{\text { Gross Profit }}{\text { Net Sales }}$ & Ratio \\
\hline $\mathrm{Y}$ & Inventory Valuation Method & $\begin{array}{l}\text { First in First Out } \text { (FIFO) } \\
\text { Weighted Average }\end{array}$ & Nominal \\
\hline
\end{tabular}

\section{Analysis Method}

There are two analytical methods used in this study. The first method utilizes a case question to answer the first hypotheses. Then, hypotheses 2, 3, 4, and 5 will be analyzed with Statistical and Services Solutions (SPSS) software version 24. The SPSS software will analyze the effect of inventory turnover, current ratio, financial leverage, and gross profit margin on selecting the inventory valuation method. The stages of analysis carried out are descriptive statistical analysis, dependent variable coding, multicollinearity test, overall model fit test, determinant coefficient test, and regression model feasibility test.

\section{Hypothesis test}

The statistical technique of multivariate test was used to test the hypothesis. The multivariate test uses logistic regression with the Backward Stepwise (WALD) method, which tests the effect of inventory turnover, current ratio, financial leverage, and gross profit margin on selecting inventory valuation methods. The dependent variable is in the form of a dummy variable. The model used is as follows:

Information:

$$
\ln \frac{P}{1-p}=\alpha+\beta_{1} \mathrm{IP}+\beta_{2} \mathrm{RL}+\beta_{3} \mathrm{FL}+\beta_{4} \mathrm{MLK}+\mathrm{e}
$$

$\mathrm{P} \quad=$ Selection of inventory valuation method

$\alpha \quad=$ Constant

$\beta \quad=$ Regression Constant

IP = Inventory Intensity

RL $=$ Current Ratio

$\mathrm{FL} \quad=$ Financial Leverage

MLK = Gross Profit Margin

$\mathrm{e} \quad=$ Error Term

Hypothesis testing on logistic regression was carried out using a significance level $(\alpha)$ of $5 \%$. The p-value determines the criteria for acceptance or rejection of this analysis. If the p-value is $>0.05$, then the null hypothesis is rejected. If the null hypothesis is rejected, the variable does not affect the selection of the inventory valuation method. If the p-value is $<0.05$, then the null hypothesis fails to be rejected. If the null hypothesis fails to be rejected, the variable does affect the selection of the inventory valuation method. 


\section{RESULTS AND DISCUSSION}

\section{Research Overview}

The data used in this study is the financial statement data of manufacturing companies in the form of balance sheets and income statements published annually on December 31. There are two purposes of this research. The first purpose will be tested using a case question. The second purpose will be tested with statistical tools using SPSS version 24. Below is the table displaying the sample that has been successfully selected for analysis:

Table 2. Analysis

\begin{tabular}{clcc}
\hline No & \multicolumn{1}{c}{ Criteria } & Company & Data \\
\hline 1. & Manufacturing company 2010-2019 & 137 & 1.370 \\
\hline 2. & Financial statements with foreign currency & $(28)$ & $(280)$ \\
\hline 3. & Not consistently publishing financial statements & $(17)$ & $(170)$ \\
\hline $4 . \quad$ Inconsistent use of inventory accounting method & $(5)$ & $(50)$ \\
\hline Total of companies that meet the sample of criteria & 87 & 870 \\
\hline Outliers & $(14)$ & $(140)$ \\
\hline Amount of Sample Data & 73 & 730 \\
\hline Source: Processed Data & &
\end{tabular}

\section{First Method With Case Question}

Inventory records of manufacturing companies engaged in trading during December 2020 are as follows:

Table 3. Inventory

\begin{tabular}{clcc}
\hline Date & \multicolumn{1}{c}{ Transaction } & Unit & Unit Cost \\
\hline December 01 & Beginning inventory & 60 & $\$ 24$ \\
\hline December 7 & Purchase & 120 & $\$ 26$ \\
\hline December 9 & Sale & 100 & $\$ 35$ \\
\hline December 11 & Purchase & 70 & $\$ 27$ \\
\hline December 15 & Sale & 65 & $\$ 40$ \\
\hline December 18 & Purchase & 80 & $\$ 28$ \\
\hline December 21 & Sale & 120 & $\$ 40$ \\
\hline Source: Processed Data & &
\end{tabular}

Additional information:

Operating expenses in December were $\$ 500$, and the assumed tax rate was 30\%.

Table 4. Inventory Additional information

\begin{tabular}{llccccc}
\hline \multirow{2}{*}{ Date } & \multirow{2}{*}{ Transaction } & \multirow{2}{*}{ Unit } & \multicolumn{2}{c}{ Cost } & \multicolumn{2}{c}{ Total } \\
\cline { 4 - 7 } Dec-1 & Beginning inventory & 60 & Unit & Price & Cost & Revenue \\
\hline Dec-7 & Purchase & 120 & $\$ 26$ & - & $\$ 3,120$ & - \\
\hline Dec-11 & Purchase & 70 & $\$ 27$ & - & $\$ 1,890$ & - \\
\hline Dec-18 & Purchase & 80 & $\$ 28$ & - & $\$ 2,240$ & - \\
\hline & Total & 330 & & & $\$ 8,690$ & \\
\hline Dec-9 & Sale & 100 & - & $\$ 35$ & - & $\$ 3,500$ \\
\hline Dec-15 & Sale & 65 & - & $\$ 40$ & - & $\$ 2,600$ \\
\hline Dec-21 & Sale & 120 & - & $\$ 40$ & - & $\$ 4,800$ \\
\hline & Total & 285 & & & & $\$ 10,900$ \\
\hline
\end{tabular}




\section{Inventory Valuation Method Using FIFO}

As previously explained, the inventory that is purchased first will be sold first. The following is a table for calculating the Cost of Goods Sold (COGS) and ending inventory using the FIFO Method.

Table 5. Inventory Valuation Method FIFO

\begin{tabular}{|c|c|c|c|c|c|c|}
\hline \multirow{2}{*}{ Date } & \multicolumn{2}{|c|}{ Purchase } & \multicolumn{2}{|c|}{ COGS } & \multicolumn{2}{|c|}{ Balance } \\
\hline & Units x Cost & Total & Units x Cost & Total & Units $x$ Cost & Total \\
\hline Dec-1 & & & & & $60 \times \$ 24$ & $\$ 1,440$ \\
\hline \multirow[t]{2}{*}{ Dec-7 } & \multirow[t]{2}{*}{$120 \times \$ 26$} & \multirow[t]{2}{*}{$\$ 3,120$} & \multirow[t]{2}{*}{ - } & \multirow[t]{2}{*}{ - } & $\begin{array}{c}60 \times \$ 24 \\
120 \times \$ 26\end{array}$ & $\begin{array}{l}\$ 1,440 \\
\$ 3,120\end{array}$ \\
\hline & & & & & Total & $\$ 4,560$ \\
\hline \multirow{2}{*}{ Dec-9 } & \multirow{2}{*}{-} & \multirow{2}{*}{ - } & $60 \times \$ 24$ & $\$ 1,440$ & \multirow[t]{2}{*}{$80 \times \$ 26$} & \multirow[t]{2}{*}{$\$ 2,080$} \\
\hline & & & $40 \times \$ 26$ & $\$ 1,040$ & & \\
\hline \multirow{3}{*}{ Dec-11 } & \multirow{3}{*}{$70 \times \$ 27$} & \multirow{3}{*}{$\$ 1,890$} & \multirow{3}{*}{-} & \multirow{3}{*}{-} & $80 \times \$ 26$ & $\$ 2,080$ \\
\hline & & & & & $70 \times \$ 27$ & $\$ 1,890$ \\
\hline & & & & & Total & $\$ 3,970$ \\
\hline \multirow{3}{*}{ Dec-15 } & \multirow{3}{*}{-} & \multirow{3}{*}{ - } & \multirow{3}{*}{$65 \times \$ 26$} & \multirow{3}{*}{$\$ 1,690$} & $15 \times \$ 26$ & $\$ 390$ \\
\hline & & & & & $70 \times \$ 27$ & $\$ 1,890$ \\
\hline & & & & & Total & $\$ 2,280$ \\
\hline \multirow{4}{*}{ Dec-18 } & \multirow{4}{*}{$80 \times \$ 28$} & \multirow{4}{*}{$\$ 2,240$} & \multirow{4}{*}{-} & \multirow{4}{*}{ - } & $15 \times \$ 26$ & $\$ 390$ \\
\hline & & & & & $70 \times \$ 27$ & $\$ 1,890$ \\
\hline & & & & & $80 \times \$ 28$ & $\$ 2,240$ \\
\hline & & & & & Total & $\$ 4,520$ \\
\hline \multirow{3}{*}{ Dec-21 } & \multirow{3}{*}{-} & \multirow{3}{*}{ - } & $15 \times \$ 26$ & $\$ 390$ & \multirow{3}{*}{$45 \times \$ 28$} & \multirow{3}{*}{$\$ 1,260$} \\
\hline & & & $70 \times \$ 27$ & $\$ 1,890$ & & \\
\hline & & & $35 \times \$ 28$ & $\$ 980$ & & \\
\hline
\end{tabular}

From the table above, the total cost of goods sold is $\$ 7,430$, and the ending inventory is $\$ 1,260$. The next step is to make an income statement to calculate the net profit.

Table 6. Income Statement I

\begin{tabular}{lc}
\hline Revenue & $\$ 10,900$ \\
\hline Less: cost of good & $\$ 7,430$ \\
\hline Gross profit & $\$ 3,470$ \\
\hline Less: operational cost & $\$ 500$ \\
\hline Profit for the year & $\$ 2,970$ \\
\hline Tax @30\% $\$ 2,970 \times 30 \%)$ & $\$ 891$ \\
\hline Net profit & $\$ 2,079$ \\
\hline
\end{tabular}

\section{Inventory Valuation Method Using Weighted Averaged}

In this method, inventory items are sold using the average unit cost of all available units.

$$
\begin{gathered}
\text { Weighted average cost }=\frac{\text { Total cost available for sale }}{\text { Total unit }} \\
\text { Weighted average cost }=\frac{\$ 8,690}{330} \$ 26.33
\end{gathered}
$$


The following table calculates the cost of goods sold and ending inventory using a weighted average.

Table 7. Calculates

\begin{tabular}{ccc}
\hline Units sold & Average cost & Amount \\
\hline 285 & $\$ 26.33$ & $\$ 7,504$ \\
\hline Remaining Units & Average cost & Amount \\
\hline 45 & $\$ 26.33$ & $\$ 1,185$ \\
\hline
\end{tabular}

Based on the table above, the next step is to make an income statement to calculate the net profit.

Table 8. Income Statement II

\begin{tabular}{lc}
\hline Revenue & $\$ 10,900$ \\
\hline Less: cost of good & $\$ 7,504$ \\
\hline Gross profit & $\$ 3,396$ \\
\hline Less: operational cost & $\$ 500$ \\
\hline Profit for the year & $\$ 2,896$ \\
\hline Tax @30\% $(\$ 2,896 \times 30 \%)$ & $\$ 869$ \\
\hline Net profit & $\$ 2,027$ \\
\hline
\end{tabular}

\section{Second Method Using Software Statistical and Services Solutions (SPSS)}

\section{Descriptive Statistical Analysis}

The table below is a table of descriptive statistical test results describing the dependent and independent variables.

Table 9. Descriptive Statistical

\begin{tabular}{lccccc}
\hline & $\mathbf{N}$ & Minimum & Maximum & mean & Std. Deviation \\
\hline Inventory Turnover & 730 & .05 & 30.72 & 4.95 & 3.59 \\
\hline Current Ratio & 730 & .02 & 11.74 & 2.18 & 1.64 \\
\hline Financial Leverage & 730 & .08 & 1.53 & .48 & .23 \\
\hline Gross Profit Margin & 730 & -5.19 & .95 & .22 & .27 \\
\hline Y & 730 & 0 & 1 & .05 & .228 \\
\hline Valid N (listwise) & 730 & & & \\
\hline
\end{tabular}

The average inventory turnover of 730 data is 4.95 . The maximum value of inventory turnover is 30.72 , owned by P.T. Nippon Indosari Corpindo Tbk, and PT Intikeramik Alamasri Industri Tbk owns the minimum value of 0.05 . Meanwhile, the standard deviation of inventory intensity is 3.59 .

The average current ratio of 730 data is 2.18 . The maximum value of the current ratio is 11.74 owned by PT Mandom Indonesia Tbk, and for a minimum value of 0.02 owned by PT Eterindo Wahanatama Tbk. Meanwhile, the standard deviation of the current ratio is 1.64 .

The average Financial Leverage of 730 data is 0.48. PT Intikeramik Alamasri Industri Tbk owns the maximum financial leverage value of 1.53, and PT Keramik Indonesia Assosiasi Tbk owns a minimum value of 0.08 . Meanwhile, the standard deviation of financial leverage is 0.27 .

The average gross profit margin of 730 data is 0.22 . PT Intikeramik Alamasri Industri Tbk owns the maximum gross profit margin of 0.95 . Furthermore, a minimum value of -5.19 is owned by PT Panasia Indosyntec Tbk. Meanwhile, the standard deviation of the gross profit margin is 0.23 .

\section{Encoding the Dependent Variables}

The following is a coding table for the dependent variable in the logistic regression model. Results of SPSS 24 shows that the Weighted Averaged method is coded 0 , and the FIFO method is coded 1. 
Table 10. Dependent Variable Encoding

\begin{tabular}{lc}
\hline \multicolumn{1}{c}{ Original Value } & Internal Value \\
\hline Weighted Average & 0 \\
\hline FIFO & 1 \\
\hline
\end{tabular}

\section{Multicollinearity Test}

The following table is a table of multicollinearity test results. From the table, it can be seen that the inventory turnover variable has a tolerance value of 0.961 and VIF 1.040, the current ratio variable has a tolerance value of 0.596 and VIF 1.678, the financial leverage variable has a tolerance value of 0.596 and VIF 1.759, and the variable gross profit margin has a tolerance value of 0.886 and VIF of 1.129 . Thus, it can be concluded that every variable below has a tolerance value of $>0.1$ and $\mathrm{VIF}<10$. The test result explains that no multicollinearity is observed in the model, or there is no strong correlation between all independent variables in this research model.

Table 11. Multicollinearity Test Results

\begin{tabular}{llll}
\hline \multirow{2}{*}{ Model } & \multicolumn{2}{c}{ Collinearity Statistics } \\
\cline { 2 - 4 } & \multicolumn{2}{c}{ Tolerance } & VIF \\
\hline \multirow{2}{*}{1} & (Constant) & & \\
\cline { 2 - 4 } & Inventory Turnover & .961 & 1.040 \\
\cline { 2 - 4 } & Current Ratio & .596 & 1,678 \\
\cline { 2 - 4 } & Financial Leverage & .569 & 1,759 \\
\cline { 2 - 4 } & Gross Profit Margin & .886 & 1,129 \\
\hline
\end{tabular}

\section{Overall Model Fit Test}

The overall model is assessed by comparing the -2 Log-Likelihood model (block number $=0$ ) before the independent variable is introduced with the -2 Log-Likelihood model (block number $=1$ ) when the independent variable is introduced. A good regression model is indicated by -2 Log-Likelihood (block number $=0$ ) $>-2$ LogLikelihood (block number $=1$ ). Below is the table denoting block 0: beginning block, and the next table denotes block 1: method $=$ Enter.

Table 12. Iteration History ${ }^{\text {B } \mathrm{C}}$

\begin{tabular}{llcc}
\hline Iteration & -2 Logs likelihood & Coefficients Constant \\
\hline & \multicolumn{1}{c}{1} & 369,818 & -1.781 \\
\cline { 2 - 4 } Step 0 & 3 & 315,017 & -2.505 \\
\cline { 2 - 4 } & 3 & 310,181 & -2.802 \\
\hline & 5 & 310.100 & -2.847 \\
\hline
\end{tabular}

a. Constant is included in the model.

b. Initial -2Log-Likelihood: 310,100

c. Estimation terminated at iteration number 5 because parameter estimates changed by less than .001 . 
Table 13. Iteration History ${ }^{\text {a } \mathrm{C} \mathrm{D}}$

\begin{tabular}{|c|c|c|c|c|c|c|c|}
\hline \multirow{2}{*}{\multicolumn{2}{|c|}{ Iteration }} & \multirow{2}{*}{-2 Logs likelihood } & \multicolumn{5}{|c|}{ Coefficients } \\
\hline & & & Constant & $\mathrm{X} 1$ & $\mathrm{X} 2$ & $\mathbf{X} 3$ & $\mathrm{X} 4$ \\
\hline \multirow{7}{*}{ Step 1} & 1 & 356,609 & -1.854 & -.031 & .072 & -.032 & .386 \\
\hline & 2 & 280,185 & -2.846 & -.086 & .142 & .016 & 1,743 \\
\hline & 3 & 260,043 & -3.452 & -.168 & .170 & -.005 & 3.543 \\
\hline & 4 & 256,994 & -3.498 & -.241 & .175 & -.096 & 4.051 \\
\hline & 5 & 256,836 & $-3,450$ & -.268 & .175 & -124 & 4.107 \\
\hline & 6 & 256,836 & -3.445 & -.270 & .175 & -.126 & 4.107 \\
\hline & 7 & 256,836 & -3.445 & -.270 & .175 & -.126 & 4.107 \\
\hline \multicolumn{8}{|c|}{ a. Method: Enter } \\
\hline \multicolumn{8}{|c|}{ b. Constant is included in the model. } \\
\hline \multicolumn{8}{|c|}{ c. Initial -2Log-Likelihood: 310,100} \\
\hline \multicolumn{8}{|c|}{$\begin{array}{l}\text { d. Estimation terminated at iteration number } 7 \text { because parameter estimates changed by less } \\
\text { than } .001 \text {. }\end{array}$} \\
\hline
\end{tabular}

The independent variable (see: Block 1) is entered into the model, and the -2 Log-Likelihood of 256,836 is obtained. Then, by calculating $(\mathrm{df})=\mathrm{N}$ - number of independent variables $-1=730-4-1=725$ the degree of freedom is obtained. The value of the Chi-square table on df 725 with a probability value of 0.05 is 788,750 . So the value of -2 Log-Likelihood (256.836) $<$ Chi-Square table (788.750). Thus, the model with the independent variable is considered fit with the data.

Based on the two tables above, we can see a comparison between -2 Log-Likelihood (block number $=0$ ), which is 310.100 , where this value is greater than -2 Log-Likelihood (block number $=1$ ), which is 256.836 . The comparison results can be concluded that the block 1 model is good because the value of -2 Log-Likelihood has decreased.

\section{Coefficient of Determination Test (Nagelkerke R Square)}

The table below is a table of the results of testing the determination coefficient. The value of Nagelkerke $\mathrm{R}$ Square indicates the magnitude of the determination coefficient in the logistic regression model.

Nagelkerke $R$ Square is a modification of the Cox and Snell coefficient, which is a measure that tries to imitate R Square in the multiple regression method. The Nagelkerke R Square value is 0.203 , which means the dependent variable can be explained by the independent variable's variability of $20.3 \%$, and the rest or $79.7 \%$ $(100 \%-20.3 \%)$ is explained by other variables.

Table 14. Model Summary

\begin{tabular}{cccc}
\hline Step & -2 Logs likelihood & Cox \& Snell R Square & Nagelkerke R Square \\
\hline 1 & $256,836^{\mathrm{a}}$ & .070 & .203 \\
\hline
\end{tabular}

\section{Regression Model Feasibility Test (Hosmer and Lemeshow's Goodness of Fit)}

Based on the regression model's feasibility test results, the chi-square value is 7.530 , the degree of freedom (df) value is 8 , and the significance probability value is 0.481 . The chi-square table for df 8 at a significance of 0.05 is 15.51 . Because the calculated chi-square value $<$ chi-square table and a significance of $0.48(>0.05)$ indicate that this logistic regression model is accepted and feasible for analysis.

Table 15. Hosmer and Lemeshow Test

\begin{tabular}{cccc}
\hline Step & Chi-square & df & Sig. \\
\hline 1 & 7,530 & 8 & .481 \\
\hline
\end{tabular}




\section{Hypothesis test}

After testing the feasibility of the logistic regression model and obtaining a fit model, so the next step is to test the hypothesis to answer the objectives of this study.

Table 16. Variables in the Equation

\begin{tabular}{|c|c|c|c|c|c|c|c|c|c|}
\hline & & \multirow{2}{*}{ B } & \multirow{2}{*}{ SE } & \multirow{2}{*}{ Wald } & \multirow{2}{*}{ df } & \multirow{2}{*}{ Sig. } & \multirow{2}{*}{$\operatorname{Exp}(B)$} & \multicolumn{2}{|c|}{ 95\% C.I.for EXP(B) } \\
\hline & & & & & & & & Lower & Upper \\
\hline \multirow{5}{*}{ Step 1a } & I.P. & -.270 & .093 & 8.376 & 1 & .004 & .763 & .636 & .917 \\
\hline & $\mathrm{RL}$ & .175 & .100 & 3.038 & 1 & .081 & 1.191 & .978 & 1.450 \\
\hline & FL & -.126 & 1.145 & .012 & 1 & .912 & .882 & .093 & 8,319 \\
\hline & MLK & 4.107 & 1.027 & 16.006 & 1 & .000 & 60,765 & 8.125 & 454.428 \\
\hline & Constant & -3.445 & .971 & 12,579 & 1 & .000 & .032 & & \\
\hline
\end{tabular}

The table above is a table of hypothesis testing results processed using binary logistic regression. The results of this test are used to see whether the variables of inventory intensity (I.P.), current ratio (R.L.), financial leverage (F.L.), and gross profit margin (MLK) affect the selection of inventory valuation methods with a significance level of $<0.05$.

The magnitude of the effect can be indicated by EXP (B) and the direction of the regression coefficient, indicated by the B value. A small S.E. value explains a more accurate or representative sample. The following is a comparison table for WALD values with a chi-square table.

Table 17. WALD Values with Chi-Square

\begin{tabular}{lcccccc}
\hline Variable & B & EXP $(\mathbf{B})$ & WALD & Chi-Square Table & Sig. & Decision \\
\hline I.P. & -.270 & .763 & 8.376 & $>3,841$ & .004 & H2 accepted \\
\hline RL & .175 & 1.191 & 3.038 & $<3,841$ & .081 & H3 rejected \\
\hline FL & -.126 & .882 & .012 & $<3,841$ & .912 & H4 rejected \\
\hline MLK & 4.107 & 60,765 & 16.006 & $>3,841$ & .000 & H5 accepted \\
\hline
\end{tabular}

The inventory turnover ratio with an odds ratio of 0.763 means that companies tend to use the FIFO method of 0.763 times compared to the weighted average method for every one-unit increase in inventory intensity.

The current ratio with an odds ratio of 1.191 means that for every one-unit increase in the current ratio, the company tends to use the FIFO method of 1.191 times compared to the weighted average method.

The financial leverage ratio with an odds ratio of 0.882 means that for every increase in one unit of financial leverage, the company uses the FIFO method of 0.882 times compared to the weighted average method.

The gross profit margin ratio with an odds ratio of 60.765 means that for every one-unit increase in gross profit margin, the company tends to use the FIFO method of 60.765 times compared to the weighted average method.

\section{The Effect of Inventory Valuation Method on Tax, Profit and Ending Inventory}

Based on the results of the calculation of the inventory valuation method using FIFO and the weighted average method case question above. So it can be concluded that the inventory valuation method using FIFO and weighted average affect taxes, profits, and ending inventory. It can be proved that the results of the calculation of taxes, profits, and ending inventory using the FIFO method are $\$ 891, \$ 2,079$, and $\$ 1,260$. While calculations using the average method have results of $\$ 869, \$ 2,027$, and $\$ 1,185$. This study is in line with Edori, D.S. (2018), which states that the selection of inventory valuation methods affects taxes, profits, and ending inventory.

The income statements for taxes, profits, and ending inventory have different values. The inventory valuation method recommended for manufacturing companies is the FIFO method because it has a net profit of $\$ 52$ compared to calculations using the weighted average method. When viewed from the net profit generated from both methods in question, it produces a net profit of $\$ 2,079$ and $\$ 2,027$. It can be concluded that FIFO is the best method. 


\section{The Effect of Inventory Turnover on Selection of Inventory Valuation Method}

Based on the results of testing the inventory turnover variable on the selection of the inventory valuation method, it can be seen that the inventory turnover variable has a significance value less than 0.05 , which is 0.004 . So it can be concluded that the inventory turnover variable has a significant effect on the inventory valuation method in manufacturing companies. This study is in line with research conducted by Gaol, R.L. (2015), which states that the inventory intensity variable affects the selection of inventory valuation methods. However, the results of this study are not in line with research conducted by Indriyani, N., and Riharjo, I.B. (2018), which states that inventory intensity does not affect the selection of inventory valuation methods.

\section{The Effect of Current Ratio on the Selection of Inventory Valuation Method.}

Testing the current ratio variable on the selection of inventory valuation methods has a significance value of 0.08 , greater than 0.05 . So it can be concluded that the current ratio variable does not affect the selection of inventory valuation methods in manufacturing companies. The results of this study are in line with the research of Victoria, N. (2016), which states that the current ratio variable does not affect the selection of the inventory valuation method. The results of this study are not in line with research conducted by Mahardika R., Nuraina, E., Widhianningrum, P. (2015), which states that the current ratio affects the selection of inventory valuation methods. The contradiction may be due to the amount of data used for 3 (three) years, while this study used data for 10 (ten) years.

\section{The Effect of Financial Leverage on the Selection of Inventory Valuation Method}

The results of testing the financial leverage variable on the selection of inventory valuation methods have a significance value greater than 0.05 , which is 0.912 . So it can be concluded that the financial leverage variable does not affect the selection of inventory valuation methods in manufacturing companies. The results of this study are in line with the research of Ayem, S. and Harjanta, A.P.P. (2018), which states that the financial leverage variable does not affect the selection of inventory valuation methods. The results of this study are not in line with research conducted by Rahmayani, A.N., and Utami, W.P. (2019), which states that financial leverage affects the selection of inventory valuation methods. The contradiction may be due to the amount of data used for 4 (four) years, while this study used data for 10 (ten) years

\section{The Effect of Gross Profit Margin on the Selection of Inventory Valuation Method}

The results of testing the gross profit margin variable on the selection of inventory valuation methods have a significance value of less than 0.05 , which is 0.000 . So it can be concluded that the variable gross profit margin affects the selection of inventory valuation methods in manufacturing companies. The results of this study are in line with the research of Kadim, A., Suratman, A. and Muis, M.A. (2019), Rahmayani, A.N., and Utami, W.P. (2019), which states that the gross profit margin variable affects the selection of inventory valuation methods.

\section{CONCLUSIONS}

1. The choice of inventory valuation method affects taxes, profits, and ending inventory.

2. The Inventory turnover affects the selection of inventory valuation methods.

3. The current ratio does not affect the selection of inventory valuation methods.

4. The Financial leverage does not affect the selection of inventory valuation methods.

5. The Gross profit margin affects the selection of inventory valuation methods. 


\section{REFERENCES}

Ayem, S., \& Harjanta, A. P. (2018). Pengaruh Ukuran Perusahaan, Variabilitas Persediaan, Kepemilikan Manajerial, Financial Leverage Dan Laba Sebelum Pajak Terhadap Pemilihan Metode Akuntansi Persediaan. Jurnal Akuntansi Dewantara.

Edori, D.S. (2018). Implication of Choice of Inventory Valuation Methods on Profit, Tax and Closing Inventory. Account and Financial Management Journal e-ISSN: 2456-3374, Volume 3 Issue 07 July, Page 16391645.

Emmanuel, O., \& Abdullahi, Y. U. (2015). Inventory Valuation Practices and Reporting: Nigerian Textile Industry Experience. Mediterranean Journal of Social Science.

Gaol, R. L. (2015). Analisis Faktor-Faktor Yang Mempengaruhi Metode Akuntansi Persediaan Pada Perusahaan Manufaktur Yang Terdaftar Di Bursa Efek Indonesia (BEI). Jurnal Riset Akuntansi \& Keuangan.

Ghozali, I. (2018). Analisis Multivariate Dan Ekonometrika E-Views 10, $2^{\text {nd }}$ Edition.

Indriyani, N., \& Riharjo, I. B. (2018). Faktor-Faktor Yang Mempengaruhi Pemilihan Metode Akuntansi Persediaan. Jurnal Ilmu Dan Riset Akuntansi.

Kadim, A., Suratman, A., \& Muis, M. A. (2019). Analisis Pengaruh Rasio Lancar, Perputaran Persediaan Dan Margin Laba Kotor Terhadap Pemilihan Metode Persediaan Pada Perusahaan Dagang yang Terdaftar Di Bursa Efek Indonesia Pada Tahun 2013-2015. Jurnal Ilmiah Manajemen Forkamma.

Mahardika, R., Nuraina, E., dan Widhianningrum, P. (2015). Analisis Faktor-Faktor Yang Berpengaruh Terhadap Pemilihan Metode Akuntansi Persediaan. Jurnal Akuntansi dan Pendidikan.

Nosiru, A. A. (2015). The Tax Effect Of FIFO And LIFO On The Profitability Of Manufacturing. Retrieved From https://www.linkedin.com/pulse/tax efefect-fifo-lifo-profitability-manufacturing nosiru?trk=public_profile_article_view

Rahmayani, A. N., \& Utami, W. P. (2019). Analisis Faktor-Faktor Yang Berpengaruh Terhadap Pemilihan Metode Akuntansi Persediaan Pada Perusahaan Manufaktur Yang Terdaftar Di BEI Tahun 2014-2017. Jurnal Riset Akuntansi Jambi.

Pernyataan Standar Akuntansi Keuangan (PSAK) No. 14. (2008).

Sekaran, U. (2003). Research Methods for Business: A Skill-Building Approach. John Wiley \& Sons.

Siyanbola, T. T. (2012). Impact of Stock Valuation on Profitability on Manufacturing Industries. International Journal of Advanced Research In Management And Social Sciences, 1(2),35-46. ISSN: 2278-6236.

Simeon, E. D., \& John, O. (2018). Implication of Choice of Inventory Valuation Methods on Profit, Tax, and Closing Inventory. Account and Financial Management Journal.

Teplicka, K., \& Senova, A. (2020). Inventory Valuation Methods and Their Impact On The Company's Profit Generation. International Scientific Journal About Logistics.

Victoria, N. (2016). Faktor Ukuran Perusahaan, Variabilitas Persediaan, Struktur Kepemilikan, Financial Leverage, Dan Rasio Lancar Dalam Pemilihan Metode Akuntansi Persediaan Pada Sub sektor Farmasi Yang Terdaftar Di BEI. Jurnal Finance.

Watts, R. L., \& Zimmerman, J. L. (1990). Positive Accounting Theory: A Ten-Year Perspective. Retrieved from The Accounting Review; Jan 1990; 65, 1; ProQuest Central pg.131.

Weygandt, J. J., Kimmel, P. D., \& Kieso, D. W. (2015). Financial Accounting.

Widarjono, A. (2007). Ekonemetrika: Teori Dan Aplikasi Untuk Ekonomi dan Bisnis. Yogyakarta: Ekonisia FE Universitas Islam Indonesia. 